\title{
Heat Treatment of Closed-Die Forgings OF LOW-ALLOY AHSS STEELS
}

\author{
Dagmar Bublíková, Štěpán Jeníček, Hana Jirková, Adam Stehlík
}
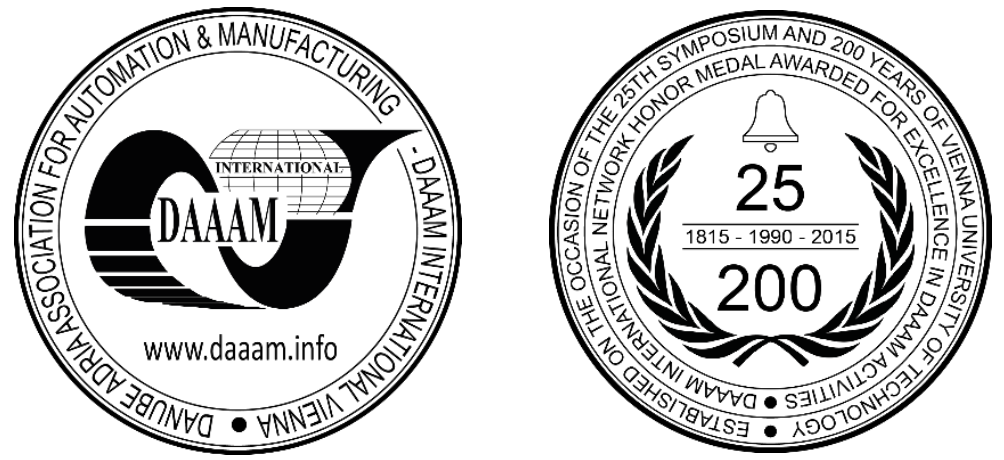

This Publication has to be referred as: Bublikova, D[agmar]; Jenicek, S[tepan]; Jirkova, H[ana] \& Stehlik, A[dam] (2018). Heat Treatment of Closed-Die Forgings of Low-Alloy AHSS Steels, Proceedings of the 29th DAAAM International Symposium, pp.0714-0718, B. Katalinic (Ed.), Published by DAAAM International, ISBN 978-3-90273420-4, ISSN 1726-9679, Vienna, Austria

DOI: $10.2507 / 29$ th.daaam.proceedings.103

\begin{abstract}
New methods are sought today for improving the mechanical properties of heavy-duty parts of high-strength steels, particularly in the automotive industry. AHS steels tend to be associated with high strength and hardness, which are achieved at the cost of poor ductility. Nevertheless, ductility can be improved: by alloying or by creating an additional phase through heat treatment. In the present study, this phase was retained austenite which, if present in a stable condition in a martensitic matrix, improves the material's ductility. The experimental steel was specially alloyed in order to depress the $\mathrm{M}_{\mathrm{s}}$ and $\mathrm{M}_{\mathrm{f}}$ temperatures. It contained 2.5\% manganese, $2.09 \%$ silicon and 1.34\% chromium, with additions of nickel and molybdenum. An actual closed-die forged part was made of this steel. This forged part was then fitted with thermocouples attached to its surface and in its interior and treated using the Q\&P process. The Q\&P process is an innovative heat treatment procedure. It is characterized by rapid cooling from the soaking temperature to a quenching temperature between the $\mathrm{M}_{\mathrm{s}}$ and $\mathrm{M}_{\mathrm{f}}$. Subsequent reheating and holding at a partitioning temperature stabilizes retained austenite in martensitic matrix. Cooling was performed in boiling water and then in still air without tempering.
\end{abstract}

Keywords: closed-die forgings; Q\&P process; retained austenite; X-ray diffraction

\section{Introduction}

A problem in current time, particularly in the forging industry, is to achieve good mechanical properties and thus long life in products at minimized costs. New methods are sought today for improving the mechanical properties of heavy-duty parts of high-strength steels, particularly in the automotive industry. One of the available heat treatment methods which can impart high strength and ductility to a material is the Q\&P process (Quenching and Partitioning), which leads to strengths in excess of $2000 \mathrm{MPa}$ and elongations of about $10 \%$ [1]. It is characterized by rapid cooling from the austenite region to a temperature between the $\mathrm{M}_{\mathrm{s}}$ and $\mathrm{M}_{\mathrm{f}}$ temperatures, during which martensite forms, whereas some austenite remains untransformed [2]. During subsequent isothermal holding, retained austenite becomes stabilised thanks to carbon which migrates from the super-saturated martensite to austenite C. According to current knowledge, this retained austenite exists primarily in the form of thin foils between martensite laths or plates [3]. 
To ensure that retained austenite becomes stabilized, it is important to use the right cooling rate and alloying strategy in order to promote the stability of retained austenite, prevent carbide precipitation within martensite and depress the $\mathrm{M}_{\mathrm{s}}$ and $\mathrm{M}_{\mathrm{f}}[4]$.

\section{Experiments}

A special composition of $0.42 \%$ carbon steel with depressed $\mathrm{M}_{\mathrm{s}}$ and $\mathrm{M}_{\mathrm{f}}$ temperatures was designed using iterative optimization in the JMatPro program [5]. The $\mathrm{M}_{\mathrm{f}}$ was below $100{ }^{\circ} \mathrm{C}$, thanks to which boiling water could be used for quenching (Tab. 1). The reduced $\mathrm{M}_{\mathrm{s}}$ and $\mathrm{M}_{\mathrm{f}}$ were due mainly to higher manganese levels, 2.5\%. Other alloying elements included silicon, chromium and molybdenum [6].

The purpose of the silicon addition was to prevent carbides from forming, to facilitate super-saturation of martensite with carbon and to provide solid solution strengthening [7]. Chromium improves hardenability and strengthens solid solution. Molybdenum was added to depress the $\mathrm{M}_{\mathrm{s}}$ and $\mathrm{M}_{\mathrm{f}}$ and to improve the stability of martensite. Nickel was added in a small amount. It makes austenite more stable during cooling, improves hardenability and provides solid solution strengthening.

\begin{tabular}{|c|c|c|c|c|c|c|c|c|c|c|c|c|}
\hline $\mathrm{C}$ & $\mathrm{Mn}$ & $\mathrm{Si}$ & $\mathrm{P}$ & $\mathrm{S}$ & $\mathrm{Cu}$ & $\mathrm{Cr}$ & $\mathrm{Ni}$ & $\mathrm{Al}$ & $\mathrm{Mo}$ & $\mathrm{Nb}$ & $\mathrm{M}_{\mathrm{s}}$ & $\mathrm{M}_{\mathrm{f}}$ \\
\hline 0.419 & 2.45 & 2.09 & 0.005 & 0.002 & 0.06 & 1.34 & 0.56 & 0.005 & 0.04 & 0.03 & 209 & 78 \\
\hline
\end{tabular}

Table 1. Chemical composition of experimental steel with reduced $\mathrm{M}_{\mathrm{s}}$ temperature [wt \%]

\subsection{Experimental heat treatment of the forged part using the $Q \& P$ process}

An engineering part was made by closed-die forging (Fig. 1) of the experimental steel. Thermocouples were attached to those locations of the part which cooled the most rapidly (surface) and the most slowly (interior). One thermocouple was attached to the surface (no. 1) and two thermocouples were placed in the part's interior (nos. 2 and 3), (Figure 1). The forged part was then $\mathrm{Q} \& \mathrm{P}$ processed using various quenching techniques.

It was heated in an air furnace at $880^{\circ} \mathrm{C}$ to a fully-austenitic condition. Relevant phase transformation temperatures were calculated using the JMatPro software. Since the special alloying depressed the $\mathrm{M}_{\mathrm{f}}$ to $78^{\circ} \mathrm{C}$ (Tab. 1), it was possible to use boiling water at $100^{\circ} \mathrm{C}$ as the quenchant. Boiling water makes a better quenchant than oil or salt baths: in terms of safety, the bath quality and degradation, as well as environmental aspects. Once the surface temperature reached approx. $100^{\circ} \mathrm{C}$, partitioning for 1 hour in a furnace at $200^{\circ} \mathrm{C}$ was carried out (Fig. 2). Data from the thermocouple at point 1 , i.e. on the surface of the forged part, showed that the quenching temperature in that location was $100^{\circ} \mathrm{C}$. At points 2 and 3, approx. $10 \mathrm{~mm}$ below the surface, the quenching temperature was higher, about $195^{\circ} \mathrm{C}$.

In another heat treatment sequence, soaking at an austenitizing temperature of $880^{\circ} \mathrm{C}$ was followed by cooling in air without partitioning (Fig. 3). In this sequence, no differences were found between cooling on the surface and in the interior of the part.

The main difference between the two sequences was in the cooling stage. Mechanical properties of specimens treated by the two schedules were compared. Miniature test specimens were employed for mapping local properties within the forged part.
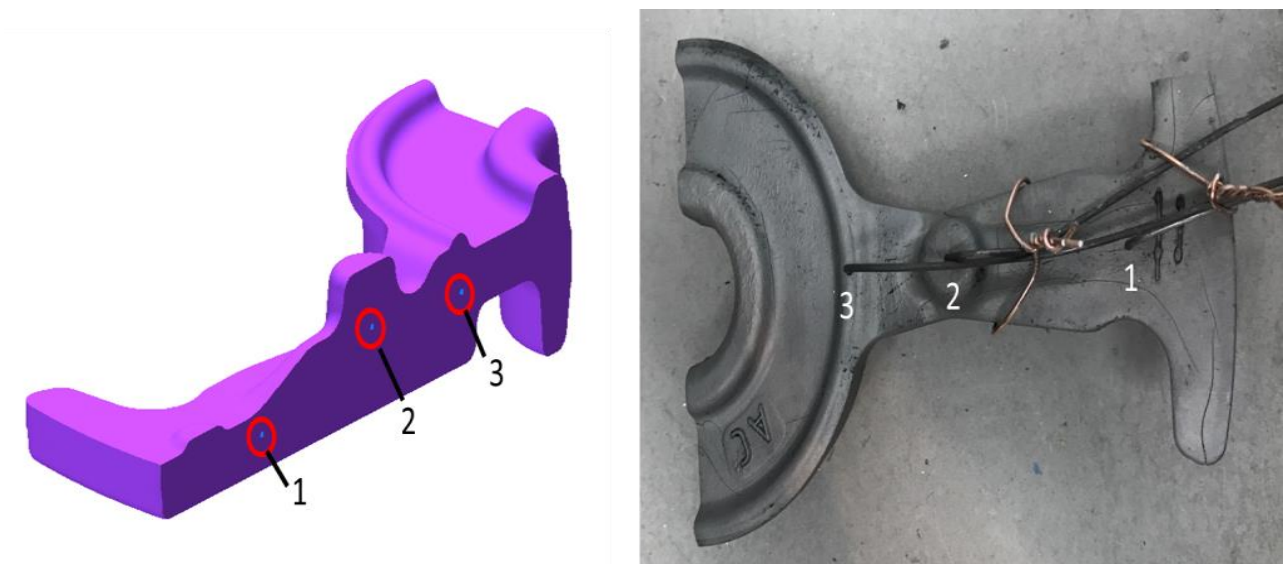

Fig. 1. Forged part of an AHS steel with thermocouples attached for experimental treatment 


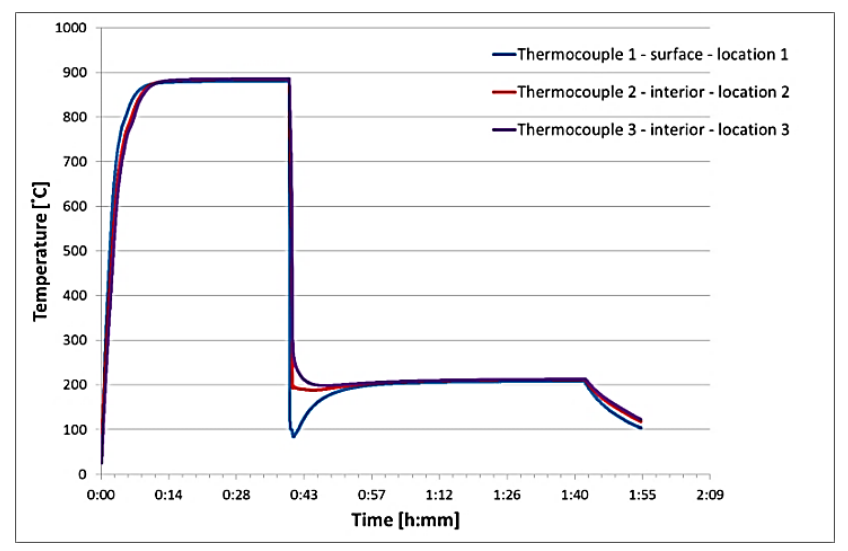

Fig. 2. Sequences of $Q \& P$ processing and quenching of the forged part in boiling water

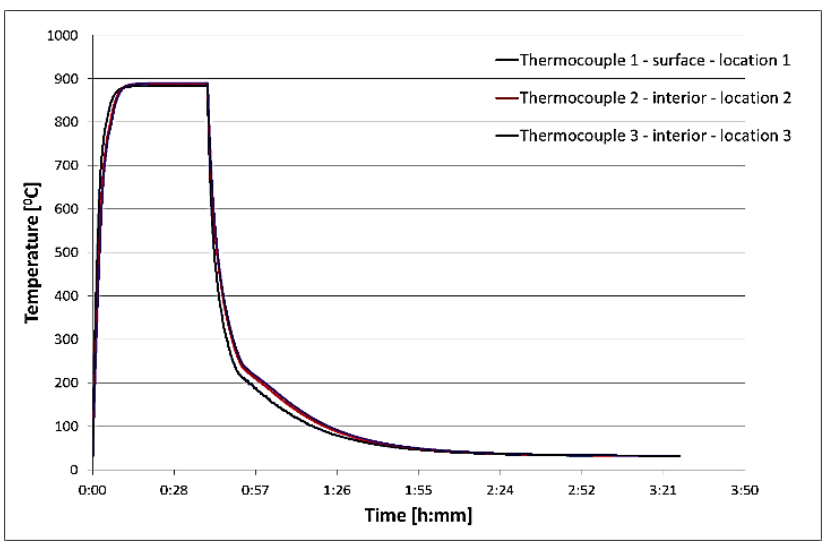

Fig. 3. Sequences of heat treatment of the forged part with cooling in still air without partitioning

\begin{tabular}{|c|c|c|c|c|c|c|c|c|}
\hline $\begin{array}{c}\text { Schedule } \\
\text { number }\end{array}$ & $\begin{array}{c}\mathbf{T}_{\mathbf{A}} \\
{\left[{ }^{\circ} \mathbf{C}\right] / \mathbf{t}_{\mathbf{A}}[\mathbf{s}]}\end{array}$ & $\begin{array}{c}\text { Thermocouple } \\
\text { location }\end{array}$ & $\begin{array}{c}\text { QT } \\
{\left[{ }^{\circ} \mathbf{C}\right]}\end{array}$ & $\begin{array}{c}\mathrm{PT}\left[{ }^{\circ} \mathrm{C} / \mathrm{s}\right] \\
/ \mathrm{t}_{\mathrm{PT}}[\mathrm{s}]\end{array}$ & $\begin{array}{c}\text { HV10 } \\
{[-]}\end{array}$ & $\begin{array}{c}\text { UTS }\left(\mathbf{R}_{\mathbf{m}}\right) \\
{[\mathrm{MPa}]}\end{array}$ & $\begin{array}{c}\text { A5mm } \\
{[\%]}\end{array}$ & $\begin{array}{l}\text { RA } \\
{[\%]}\end{array}$ \\
\hline \multirow{2}{*}{1} & \multirow{4}{*}{$880 / 2400$} & Surface & 100 & $200 / 3600$ & 603 & 2131 & 13 & 12 \\
\hline & & Interior & 195 & $200 / 3600$ & 643 & - & - & 9 \\
\hline \multirow[b]{2}{*}{2} & & Surface & RT & - & 677 & 1841 & 2 & 8 \\
\hline & & Interior & RT & - & 663 & - & 1 & 6 \\
\hline
\end{tabular}

Table 2. Heat treatments applied to the forging and results of mechanical testing $(\mathrm{RT}=$ room temperature)

\section{Discussion of results}

The first heat treatment sequence, which involved Q\&P processing, produced a predominantly martensitic microstructure with bainite and varying amounts of retained austenite (Fig. 4 a - Fig. 5 b). Fractions of retained austenite in the martensitic matrix varied with local cooling rates. High cooling rate in the surface (location 1) led to a strength of approximately $2130 \mathrm{MPa}$, combined with an elongation of almost 13\% (Tab. 2).

A relatively large volume fraction of retained austenite $(12 \%)$ in a martensitic matrix was detected by X-ray diffraction analysis and confirmed by observation of special two-stage-etched metallographic sections under a light microscope ( $1^{\text {st }}$ etching step: nital, $2^{\text {nd }}$ step: $10 \%$ aqueous solution of $\mathrm{Na}_{2} \mathrm{~S}_{2} \mathrm{O}_{5}$ ), (Figure $4 \mathrm{~b}$ ). Retained austenite was identified to be not only in the granular form but also between martensite needles.

In location 2, i.e. in the interior of the part which experienced slower cooling, the fraction of retained austenite was lower: $9 \%$. As the material cooled from the partitioning temperature of $200^{\circ} \mathrm{C}$, retained austenite decomposed into martensite.

The $9 \%$ amount of retained austenite was confirmed by metallographic observation of a section after a special etch. In contrast to the surface, austenite was mostly in the granular form and much less between martensite needles (Fig. 5 b). In this interior location, the hardness was $643 \mathrm{HV} 10$, whereas the surface hardness was only 603 HV10 (Tab. 2).

The second sequence involved cooling in still air but no partitioning at $200^{\circ} \mathrm{C}$. It produced a martensitic microstructure with a small amount of bainite and unstable retained austenite. In this sequence, the difference between cooling rates in the surface and in the interior was very small (Fig. 3).

Owing to a very slow cooling rate, a large fraction of austenite transformed to martensite. The remaining austenite had insufficient stability. Most of it was in the globular form. Thanks to a large fraction of martensite in the final microstructure, the hardness was very high: $670 \mathrm{HV} 10$. The ultimate strength was $1841 \mathrm{MPa}$ and elongation reached $2 \%$ (Tab. 2). 

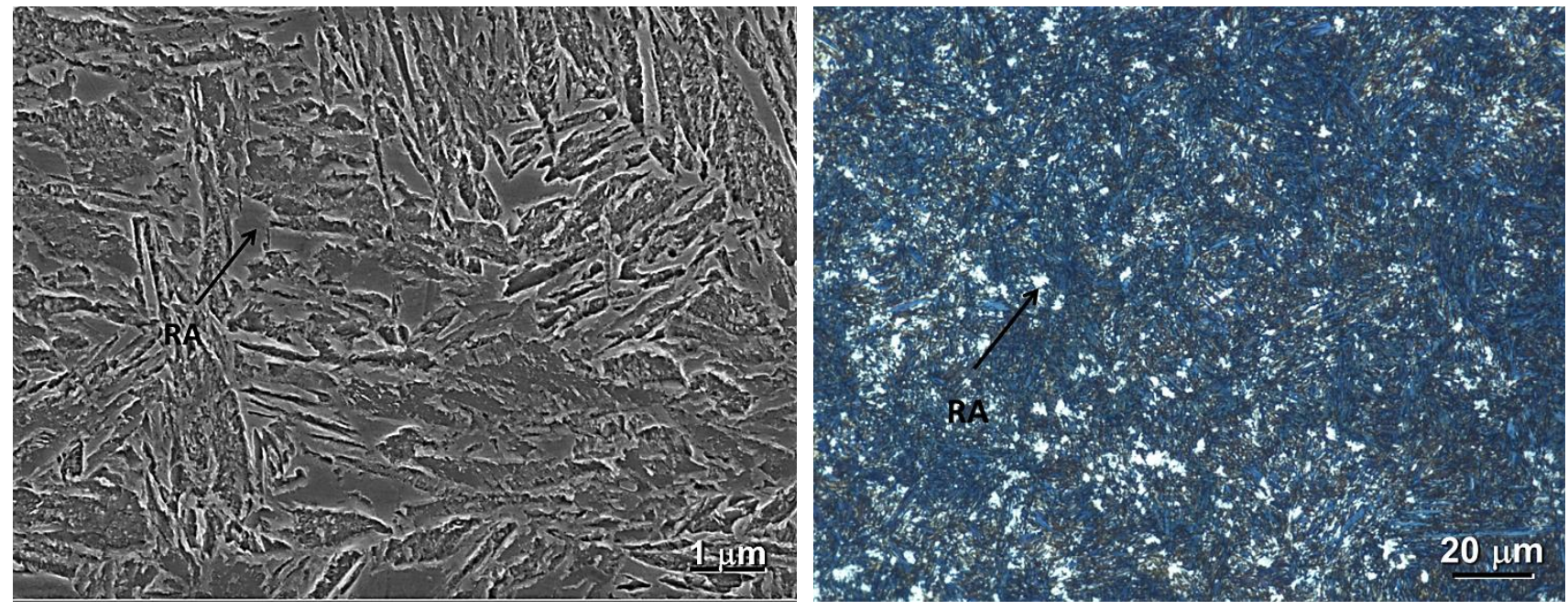

Fig. 4 a. Sequence 1 - surface of the forged part, martensitic microstructure with bainite and retained austenite, Q\&P process with boiling water, detail scanning electron micrograph

Fig. 4 b. Sequence 1 - surface of the forged part, colour etch to reveal retained austenite, optical micrograph
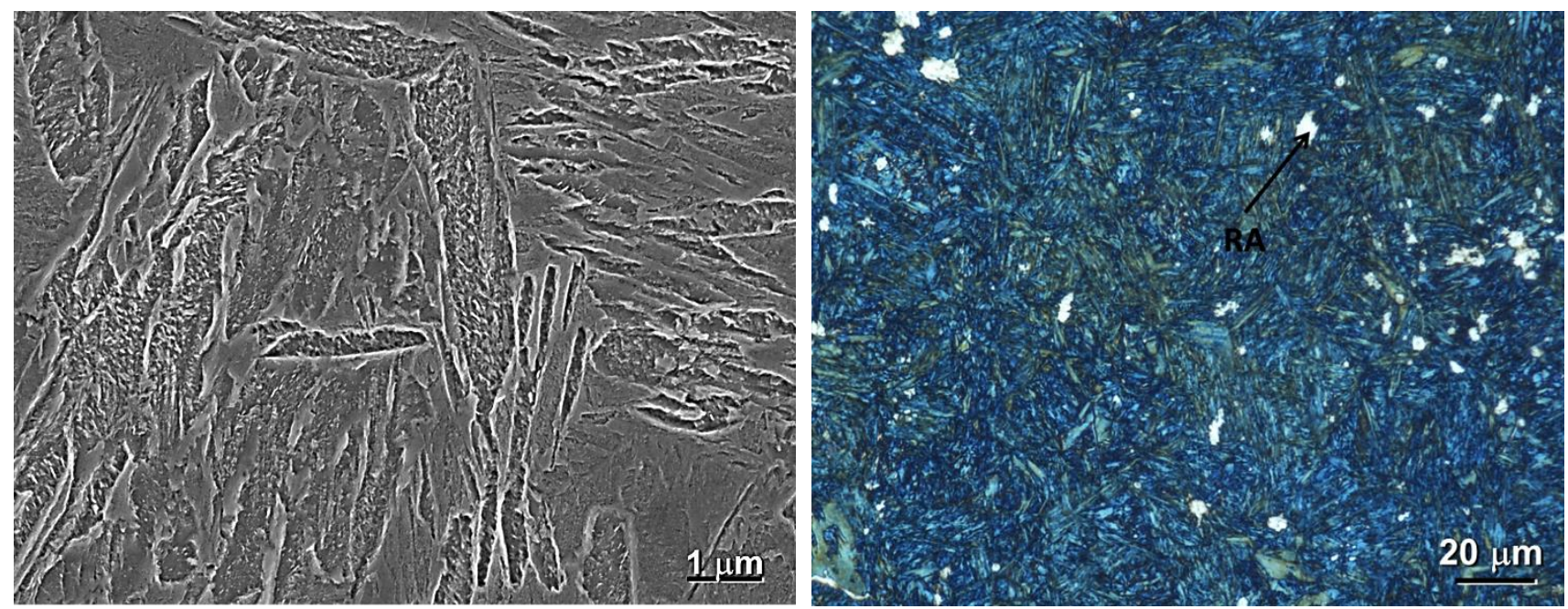

Fig. 5 a. Sequence 1 - interior of the forged part, martensitic microstructure with bainite and retained austenite, Q\&P process with boiling water, detail scanning electron micrograph

Fig. 5 b. Sequence 1 -interior of the forged part, colour etch to reveal retained austenite, optical micrograph

\section{Conclusion}

Two heat treatment sequences with different cooling methods were applied to an experimental forged part of AHS steel.

The first one involved the Q\&P process, a modern type of heat treatment. It included quenching in boiling water and partitioning in a furnace. The difference between the cooling rates in the surface and the interior proved to have a strong influence on the amount of retained austenite in the martensitic matrix. At the highest cooling rate, i.e. in the surface of the forged part which cooled in boiling water, austenite did not transform to martensite and a large part of it remained $(12 \%)$ in the microstructure even at room temperature, thanks to the composition and alloying of the steel. The resultant elongation was high, up to $13 \%$, and the ultimate strength reached approximately $2100 \mathrm{MPa}$. At the slower cooling rate, in the interior of the part, the retained austenite fraction was $9 \%$. The higher hardness resulted from the larger amount of martensite. The second sequence only involved cooling in still air, and no partitioning. Very slow cooling and the absence of isothermal holding, which otherwise would have facilitated migration of carbon from super-saturated martensite, have resulted in insufficient stability and eventual decomposition of austenite. Owing to a large fraction of martensite, the resultant hardness was $670 \mathrm{HV} 10$. Without partitioning and tempering, the martensitic microstructure failed to achieve the desired toughness. Elongation was very low, a mere $2 \%$. 
Experimental heat treatment of a complex-shaped forged part demonstrated the major impact of cooling rate on the resultant fraction of retained austenite, and thus on mechanical properties. Based on data measured in a real-world process, heat treatments with a wide range of parameters will be replicated using physical simulation under laboratory conditions. Specimens obtained in this manner will be compared with those from an actual forged part. This method will become useful in optimizing heat treatment of closed-die forgings in the forging industry.

\section{Acknowledgments}

This paper includes results achieved within the project SGS-2016-060 Research of Modern AHS Steels and Innovative Processing for their Manufacturing. The project is subsidised from specific resources of the state budget for research and development.

\section{References}

[1] Zhu, Y. et al. (2012). Stepping-quenching-partitioning treatment of 20SiMn2MoVA steel and effects of carbon and carbide forming elements. Sci China Tech Sci 2012, 55, 1838-1843

[2] Edmondsa, D.V.; Hea, K.; Rizzo, F.C.; De Coomanc, B.C.; Matlock, D.K.; Speer, J.G. (2006). Quenching and partitioning martensite - A novel steel heat treatment, Materials Science and Engineering A, Vol. 438-440, pp. 25-34, https://doi.org/10.1016/j.msea.2006.02.133

[3] Jeníček, Š.; Bublíková, D.; Jirková, H.; Káňa, J. (2017) Stability of retained austenite in high-strenght martensitic steels during cold deformation, In Daaam 2017. Vienna: Daaam International Vienna, pp. 0289-0294, ISBN: 9783-902734-07-5, ISSN: 1726-9679, DOI: 10.2507/28th.daaam.proceedings.039

[4] Qian, Z.; Lihe, Q.; Jun, T.; Jiangying, M.; Fucheng, Z. Inconsistent effects of mechanical stability of retained austenite on ductility and toughness of transformation-induced plasticity steels, Materials Science \& Engineering A, Vol. 578, 2013, pp. 370-376, doi: 10.1016/j.msea.2013.04.096.

[5] JMatPro; Release 9.0; Sente Software Ltd.; 2016

[6] Koistinen, D.P. (1959) Marburger, R.E. A general equation prescribing the extent of the austenite-martensite transformation in pure iron-carbon alloys and lain carbon steels. Acta Metallurgica, Vol. 7, pp. 59-60

[7] Jirková, H.; Kučerová, L.; B. Mašek, B. (2012). Effect of Quenching and Partitioning Temperatures in the Q-P Process on the Properties of AHSS with Various Amounts of Manganese and Silicon, Materials Science Forum, Vol. 706-709, pp. 2734-2739, doi: 10.4028/www.scientific.net/MSF.706-709.2734 